\title{
A Study on Characteristics of Atmospheric Heavy Metals in Subway Station
}

\author{
Chun-Huem Kim, Dong-Chul Yoo, Young-Min Kwon, Woong-Soo Han, Gi-Sun Kim, \\ Mi-Jung Park, Young Soon Kim and Dalwoong Choi \\ College of Health Sciences, Korea University, Seoul 136-703, Korea
}

(Received December 18, 2009; Revised December 24, 2009; Accepted December 26, 2009)

\begin{abstract}
In this study, we investigated the atmospheric heavy metal concentrations in the particulate matter inside the subway stations of Seoul. In particular, we examined the correlation between the heavy metals and studied the effect of the heavy metals on cell proliferation. In six selected subway stations in Seoul, particulate matter was captured at the platforms and 11 types of heavy metals were analyzed. The results showed that the mean concentration of iron was the highest out of the heavy metals in particulate matter, followed by copper, potassium, calcium, zinc, nickel, sodium, manganese, magnesium, chromium and cadmium in that order. The correlation analysis showed that the correlations between the heavy metals was highest in the following order: (Cu vs $\mathrm{Zn}$ ), (Ca vs Na), (Ca vs Mn), (Ni vs Cr), (Na vs Mn), (Cr vs Cd), (Zn vs Cd), (Cu vs Cd), (Ni vs Cd), (Cu vs Ni), (K vs Zn), (Cu vs K), (Cu vs Cr), (K vs Cd), (Zn vs Cr), (K vs Ni), (Zn vs $\mathrm{Ni}$ ), ( $\mathrm{K}$ vs $\mathrm{Cr}$ ), and (Fe vs $\mathrm{Cu}$ ). The correlation coefficient between zinc and copper was 0.937 , indicating the highest correlation. Copper, zinc, nickel, chromium and cadmium, which are generated from artificial sources in general, showed correlations with many of the other metals and the correlation coefficients were also relatively high. The effect of the heavy metals on cell proliferation was also investigated in this study. Cultured cell was exposed to $10 \mathrm{mg} / l$ or $100 \mathrm{mg} / l$ of iron, copper, calcium, zinc, nickel, manganese, magnesium, chromium and cadmium for 24 hours. The cell proliferation in all the heavy metal-treated groups was not inhibited at $10 \mathrm{mg} / \mathrm{l}$ of the heavy metal concentration. The only exception to this was with the cadmium-treated group which showed a strong cell proliferation inhibition. This study provides the fundamental data for the understanding of simultaneous heavy metal exposure tendency at the time of particulate matter exposure in subway stations and the identification of heavy metal sources. Moreover, this study can be used as the fundamental data for the cell toxicity study of the subway-oriented heavy metalcontaining particulate matter.
\end{abstract}

Key words: Heavy metal, Subway station, Concentration, Correlation, Cell proliferation

\section{INTRODUCTION}

Subway stations are one of the most used public facilities with the greatest number of people (Bruce, 1990; Nero, 1988). The daily average number of passengers of the subways in Seoul is 2,935,218/day for the numbers 1, 2, 3 and 4 lines (Seoul Metro Transportation Record of the year 2008). For numbers 5, 6, 7 and 8 lines, there were 1,641,808 passengers per day (Subway Getting On and Off Data' in each station and each month in 2008). This shows that many of the Seoul citizens use the subway for transportation. As the duration for staying in the subway station increases, the potential exposure to the risky environment including the

Correspondence to: Dalwoong Choi, College of Health Sciences, Korea University, Seoul, Korea

E-mail: dwlove@korea.ac.kr hazardous heavy metal-containing particulate matters in the atmosphere also increases.

In Korea, the Underground Air Quality Control Act regulated the indoor air quality in subway stations and underground locations larger than $2000 \mathrm{~m}^{2}$ before 2003. This Act recognized the risk of heavy metal contamination and efforts to reduce the risk. The Act was integrated to the Indoor Air Quality Control in Public Use Facilities Act in May, 2003 and adopted and enforced as the law of the Ministry of Environment. 10 items are regulated by the Indoor Air Quality Control Act with the maintenance standards and recommendation standards. The indoor air quality maintenance standards are for $\mathrm{PM}_{10}, \mathrm{CO}_{2}, \mathrm{HCHO}$, total bio-aerosol and $\mathrm{CO}$. The indoor air quality recommendation standards are for $\mathrm{NO}_{2}$, Radon, Volatile organic compounds, asbestos and ozone. Only one item, $\mathrm{PM}_{10}$, is regulated with respect to particulate matter standard by the Indoor Air Quality Con- 
trol Act. However, the $\mathrm{PM}_{10}$ standard is too inclusive and limited for the heavy metal control in closed public use facilities such as subway stations, since heavy metals are often scattered as they are contained in particulate matter. Few relevant studies on subway environment have been performed in recent times to evaluate such limitation. In fact, domestic studies regarding the evaluation of subway atmospheric heavy metals were continuously reported from 1996 to 2003. But recent research publication on domestic studies is insufficient.

Heavy metals are easily absorbed in the suspended particulate matter which has a small size and thus has a large surface area. The particulate matter of which diameter is less than $10 \mu \mathrm{m}$ (PM-10) are respirable particles that increase the pollutant penetration rate into the lungs when inhaled into the human body (Lebowitz, 1996; Part, 2004; Pope, 1991). As the heavy metal content increases in the suspended particulate matter in indoor air, the accumulation rate of heavy metal in the body also increases as well as the hazard. For example, it has been reported that the respirable particulate matter whose aerodynamic diameter is less than $10 \mu \mathrm{m}$ and that contains heavy metals can affect the eyes and nasal mucosa and cause respiratory diseases (Lebowitz, 1996; Pope, 1991).

At present, the risk assessment of subway-oriented heavy metal particulate matter to the living body has been conducted mainly by in vitro human lung cell experiments. It has been reported that such heavy metal particulate matters cause oxidative stress, DNA damage and inflammatory reaction (Karlsson et al., 2005, 2006; Seaton et al., 2005). Studies on the risk of subway heavy metal particulate matter to the living body are very much limited at present since it is not easy to apply a living body model to the risk of subwayoriented heavy metal particulate matter. Although efforts have been taken to improve the indoor air quality in subway stations, recent fundamental data regarding domestic subway heavy metal particulate matter are lacking. In this study, to obtain the fundamental data for the risk assessment of the subway heavy metal particulate matter to the living body, the heavy metal concentrations in the atmospheric particulate matter in the six subway stations in Seoul were investigated and the correlations between the measured heavy metals were analyzed. The effect of the heavy metals on cell proliferation was also investigated.

\section{MATERIALS AND METHODS}

Sampling method. Six subway stations in Seoul were chosen and the heavy metals in the atmospheric particulate matter were captured 3 to 5 times in each subway station platform during day time in 2007. The Leland Legacy Sample Pump (SKC Gulf Coast Inc., USA) was used to capture the heavy metals in the subway station platform atmospheric particulate matter on the filters. The MCC Filter was inserted at the front side of the pump and the air was collected to capture heavy metals at the flow rate of $10 \mathrm{ll}$ min for 30 minutes at the $1.5 \mathrm{~m}$ level. The flow rates were measured five times before and after the sampling and calibrated. The filters were kept in an auto desiccator until the mass became constant and they were weighed accurately in a $0.1 \mathrm{mg}$ unit with a scale for analytical purpose. After the sampling, the filters were dried in a desiccator, measured, weighed, and stored in the desiccator again until the analysis.

Analysis method. To analyze the captured heavy metals, the filter was pretreated with microwaves. The filters were put into a Teflon vessel to which $70 \%$ nitric acid $5 \mathrm{~m} l$ and distilled deionized water (DDW) $5 \mathrm{ml}$ were added. After closing the top, the samples were decomposed with the microwave digestion system (Ethos, Millestone). For the decomposition, the temperature was increased to $170^{\circ} \mathrm{C}$ for 15 minutes in the first step and the temperature was maintained at $170^{\circ} \mathrm{C}$ for 15 minutes in the second step. In the third step, the vessel was cooled down to room temperature for 120 minutes. The pretreated samples were diluted with DDW. The heavy metals analysis was carried out with an induced coupled plasma-mass spectrometer. In this study, the following 11 types of heavy metals were analyzed and quantified: iron $(\mathrm{Fe})$, copper $(\mathrm{Cu})$, potassium $(\mathrm{K})$, calcium (Ca), zinc ( $\mathrm{Zn})$, nickel $(\mathrm{Ni})$, sodium $(\mathrm{Na})$, manganese $(\mathrm{Mn})$, magnesium $(\mathrm{Mg})$, chromium $(\mathrm{Cr})$ and cadmium $(\mathrm{Cd})$. In addition, the correlations between the heavy metals in the atmospheric particulate matter were analyzed using the Pearson Product Moment correlation coefficients.

Materials. Fetal Bovine Serum was purchased from GibcoBRL and MEM cell culture medium from Cambrex. Other reagents were purchased from Sigma.

Cell culture. The HepG2 cells used in the experiment were cultured at $5 \% \mathrm{CO}_{2}$ and $37^{\circ} \mathrm{C}$ in the MEM medium containing $10 \%$ fetal calf serum, 100 units $/ \mathrm{m} l$ penicillin, $100 \mu \mathrm{g} / \mathrm{m} l$ streptomycin and $2 \mathrm{mM}$ glutamine. The heavy metals (HPS, Canada) were treated for 24 hours at the concentration of $10 \mathrm{mg} / \mathrm{l}$ or $100 \mathrm{mg} / \mathrm{l}$ to the cultured cells and the cell proliferation was measured after the treatment.

Cell proliferation assay. The cell proliferation rate was measured using 3-(4,5-dimethylthiazol-2-yl)-2,5-diphenyltetrazolium bromide (Hansen, 1989). Approximately 20,000 cells were cultured in 24-well plate for 24 hours and the heavy metals were treated to the cells. 3-(4,5-dimethylthiazol-2-yl)-2,5-diphenyltetrazoliumbromide was added to $0.5 \%$ and the cell culture continued for 1 hour at $37^{\circ} \mathrm{C}$. After removing the medium, dimethyl sulphoxide was added to each well to dissolve the generated blue formazan and the absorbance was measure at $570 \mathrm{~nm}$ to use the result as the cell proliferation indicator. 
Statistical analysis of data. The experimental data were analyzed using Student's $t$-test. The difference between groups was regarded as significant when the $P$ value was less than 0.05 and marked with "**". The correlations between the heavy metals in the atmospheric particulate matter were analyzed using Pearson Product Moment correlation coefficients.

\section{RESULTS}

Concentrations of air heavy metals in subway station. In six selected subway stations in Seoul, particulate matter was captured at the platforms and 11 types of heavy metals were analyzed. The results showed that the mean concentration of iron was the highest (average $8.727 \mu \mathrm{g} / \mathrm{m}^{3}$ ) out of the heavy metals in particulate matter, followed by copper (average $2.468 \mu \mathrm{g} / \mathrm{m}^{3}$ ), potassium (average $1.835 \mu \mathrm{g} / \mathrm{m}^{3}$ ), calcium (average $1.045 \mu \mathrm{g} / \mathrm{m}^{3}$ ), zinc (average $0.584 \mu \mathrm{g} / \mathrm{m}^{3}$ ), nickel (average $0.379 \mu \mathrm{g} / \mathrm{m}^{3}$ ), sodium (average $0.349 \mu \mathrm{g} / \mathrm{m}^{3}$ ), manganese (average $0.149 \mu \mathrm{g} / \mathrm{m}^{3}$ ), magnesium (average $0.049 \mu \mathrm{g} / \mathrm{m}^{3}$ ), chromium (average $0.032 \mu \mathrm{g} / \mathrm{m}^{3}$ ) and cadmium (average $0.008 \mu \mathrm{g} / \mathrm{m}^{3}$ ) in that order (Fig. 1). The iron concentration was highest among the heavy metals in the particulate matter in all the subway station platforms. In most of the subway station platform particulate matter, the concentrations of copper, potassium and calcium were highest after iron. Zinc, nickel, sodium and manganese formed the next concentration group.

In this study, iron showed the highest average concentration $8.73 \mu \mathrm{g} / \mathrm{m}^{3}$ in the subway station atmosphere. Seaton (2001) also reported that iron oxide content was the highest at $64 \sim 71 \%$ followed by chromium, manganese and copper in order from the particulate matter measurement results. Kang et al. (2008) also reported similar results from the analysis of the subway station atmosphere in Seoul. Several previous studies reported that the weight concentration of Fe-containing particles is the highest among the particles found in subway stations (Seaton et al., 2005; Kang et al., 2008). When compared with our results, the iron, manganese and chromium concentrations were higher in the subway stations of New York (Chillrud et al., 2004). In this

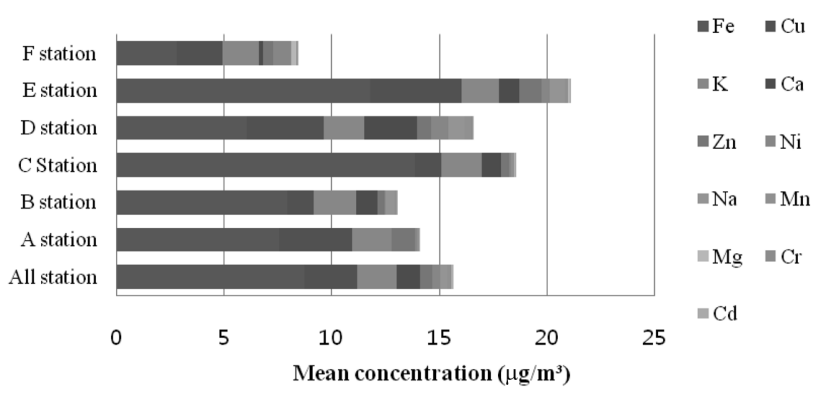

Fig. 1. Mean concentration of air heavy metals in each subway station. study, the average iron concentration was $8.73 \mu \mathrm{g} / \mathrm{m}^{3}$, lower than the heavy metal analysis results in most of the other domestic and international studies (Chillrud et al., 2004; Furuya et al., 2001; Jeon et al., 1996).

The high concentration of iron is assumed to be the result of iron abrasion by the friction between the wheel and rail, brake abrasion, and the abrasion of power cable (Adams, 2001; Johanson and Johanson, 2003; Kwon and Son, 1985; Sitzmann et al., 1999). It has also been reported that iron in the atmosphere easily crumbles by oxidation and generates particulate matter (Jeong et al., 1987). While the iron-containing particles are generated indoors at the rail-wheelbrake interfaces, other particles can flow in from the outdoor urban atmosphere. $\mathrm{Ca}(\mathrm{NO} 3, \mathrm{SO} 4),(\mathrm{Na}, \mathrm{Mg})-(\mathrm{NO} 3$, SO4) were also found in $1.8 \sim 8.0 \%$ range in the study of Kang et al. (2008). The significant quantity of calcium, sodium and magnesium was also measured in our study.

The average copper concentration level was $2.47 \mu \mathrm{g} / \mathrm{m}^{3}$ which was similar to the results of Jeon et al. (1996), 2.92 $\mu \mathrm{g} / \mathrm{m}^{3}$, and Kim et al. (1998), $1.72 \pm 0.81 \mu \mathrm{g} / \mathrm{m}^{3}$. Our results were slightly higher than results from other countries. It is assumed that the high concentration of copper is due to the copper lines for power transmission as they serve as the major sources (Harrison et al., 1983; Hopke et al., 1980).

Almost no study has been reported regarding potassium levels in Korea, but many studies have been reported from foreign countries (Adams, 2001; Furuya et al., 2001).

Although calcium has not been measured in other papers, Park (2004) reported that the calcium concentration level was $2.96 \pm 8.93 \mu \mathrm{g} / \mathrm{m}^{3}$, an average which was similar to our result. In the cases of foreign countries, calcium concentration has been investigated a lot and the calcium concentration in our result is in the similar range (Furuya et al., 2001; Gomez-Perales et al., 2005; Salma et al., 2007). The major source of calcium is in the construction materials such as cement. It was known that the particles containing iron and calcium are generated by the friction between the brake block composed of $\mathrm{CaCO}_{3}$ and the train wheels (Sitzmann et al., 1999).

Zinc has not been measured frequently in domestic studies, but the zinc concentration was $0.81 \pm 0.94 \mu \mathrm{g} / \mathrm{m}^{3}$ in the study of Park (2004) which was not very different from our result. In many studies of foreign countries, zinc was measured and the results are similar to our result (Adams, 2001; Gomez-Perales et al., 2005; Furuya et al., 2001).

Nickel concentration in subway stations has not been measured frequently in domestic studies. The nickel concentration measured in Moon and Lee (1999) was $1.51 \pm$ $0.23 \mu \mathrm{g} / \mathrm{m}^{3}$ and $0.20 \pm 0.66 \mu \mathrm{g} / \mathrm{m}^{3}$ in Park (2004) which are similar to our result. The nickel concentration was measured in many studies of foreign countries. For example, the nickel concentration was $0.70 \mu \mathrm{g} / \mathrm{m}^{3}$ in Tokyo (Furuya et al., 2001) and $0.11 \mu \mathrm{g} / \mathrm{m}^{3}$ in Prague (Sysalova and Szakova, 2006), similar to our result. 
Sodium has not been studied much in Korea or in other countries. The result in Tokyo (Furuya et al., 2001) was $0.50 \mu \mathrm{g} / \mathrm{m}^{3}$ average, which was also similar to our result.

The results from Helsinki (Aarnio et al., 2005) showed that the iron concentration was the highest among the particulate matter and manganese, copper, chromium and nickel also existed at lower concentrations than that of iron. The manganese concentration was lower than the iron concentration also in our study. The average manganese concentration in this study was $0.15 \mu \mathrm{g} / \mathrm{m}^{3}$, a little lower than the result of Park (2004), $0.61 \pm 2.09 \mu \mathrm{g} / \mathrm{m}^{3}$. Manganese has been actively studied in foreign countries and the results in our study were lower than the results from London (Adams, 2001), $1.67 \mu \mathrm{g} / \mathrm{m}^{3}$, and Prague (Sysalova and Szakova, 2006), $1.42 \mu \mathrm{g} / \mathrm{m}^{3}$. But they were similar to the results from New York (Chillrud et al., 2004), $0.24 \mu \mathrm{g} / \mathrm{m}^{3}$, Mexico City (Gomez-Perales, 2005), $0.07 \mu \mathrm{g} / \mathrm{m}^{3}$, and Budapest (Salma et al., 2007), $0.31 \mu \mathrm{g} / \mathrm{m}^{3}$. One hypothesis concerning the sources of manganese may be the increase in the surface automobile traffic density and the other may be the manganese generated from the friction corrosion of the subway rail (Boudia et al., 2006).

Magnesium has not been studied much in Korea or in other countries. Our result, $0.05 \mu \mathrm{g} / \mathrm{m}^{3}$ in average, was similar to the result in the Tokyo subway (Furuya et al., 2001), $0.04 \mu \mathrm{g} / \mathrm{m}^{3}$.

The chromium concentration in our result was similar to the results from other domestic studies or lower. The mean chromium concentration in our result was $0.032 \mu \mathrm{g} / \mathrm{m}^{3}$, similar to the result of Kim et al. (1998), $0.057 \pm 0.022 \mu \mathrm{g} / \mathrm{m}^{3}$. There is a relatively large deviation in the chromium concentration between the domestic reports. Chromium has been actively studied in foreign countries and the result in our study was similar to the result from London (Adams, 2001), $0.03 \mu \mathrm{g} / \mathrm{m}^{3}$, New York (Chillrud et al., 2004), 0.08 $\mu \mathrm{g} / \mathrm{m}^{3}$, Tokyo (Furuya et al., 2001), $0.06 \mu \mathrm{g} / \mathrm{m}^{3}$, and Budap- est (Salma et al., 2007), $0.04 \mu \mathrm{g} / \mathrm{m}^{3}$.

The mean cadmium concentration in our result was 0.008 $\mu \mathrm{g} / \mathrm{m}^{3}$ which was similar to the result from the domestic study of Kim et al. (1998), $0.005 \pm 0.004 \mu \mathrm{g} / \mathrm{m}^{3}$, and the result in Prague (Sysalova and Szakova, 2006), $0.010 \mu \mathrm{g} / \mathrm{m}^{3}$.

Correlations of air heavy metals. The correlations between the 11 heavy metals were analyzed by using the Pearson Product Moment correlation coefficient (Table 1). The analysis showed the following correlations between heavy metals in order of the correlation coefficient: $((\mathrm{Cu}$ vs $\mathrm{Zn}),(\mathrm{Ca}$ vs $\mathrm{Na}),(\mathrm{Ca}$ vs $\mathrm{Mn}$ ), (Ni vs $\mathrm{Cr}$ ), (Na vs $\mathrm{Mn}),(\mathrm{Cr}$ vs $\mathrm{Cd}),(\mathrm{Zn}$ vs $\mathrm{Cd}),(\mathrm{Cu}$ vs $\mathrm{Cd}),(\mathrm{Ni}$ vs $\mathrm{Cd}),(\mathrm{Cu}$ vs $\mathrm{Ni}),(\mathrm{K}$ vs $\mathrm{Zn}),(\mathrm{Cu}$ vs $\mathrm{K}),(\mathrm{Cu}$ vs $\mathrm{Cr}),(\mathrm{K}$ vs $\mathrm{Cd}),(\mathrm{Zn}$ vs $\mathrm{Cr})$, (K vs $\mathrm{Ni}),(\mathrm{Zn}$ vs $\mathrm{Ni})$, ( $\mathrm{K}$ vs $\mathrm{Cr}$ ) and (Fe vs $\mathrm{Cu})$ ). The correlation coefficient between zinc and copper was 0.937 , indicating the highest correlation. Out of the major heavy metals, chromium and nickel $(\mathrm{r}=0.758)$, cadmium and chromium $(\mathrm{r}=0.722)$, zinc and cadmium $(\mathrm{r}=0.658)$, copper and cadmium $(\mathrm{r}=0.649)$ and nickel and cadmium $(\mathrm{r}=0.527)$ showed relatively high correlations. Copper, zinc, nickel, chromium and cadmium, which are generated from artificial sources in general, showed correlations with many of the other metals and the correlation coefficients were also relatively high. On the contrary, calcium, sodium, manganese, and magnesium, which are usually generated from natural sources, showed little correlations with other metals and the correlation coefficients were also relatively small. The correlation coefficients of iron with other heavy metals were relatively small. The correlation between iron and copper of which concentrations are highest in most of subway stations were examined and a significant correlation was found with the $P$ value of 0.043 .

Effects of heavy metals on cell proliferation. In this study, we also investigated the effect of the heavy metals on

Table 1. Correlation coefficient of heavy metals

\begin{tabular}{|c|c|c|c|c|c|c|c|c|c|c|c|c|c|}
\hline & $\mathrm{Fe}$ & $\mathrm{Cu}$ & $\mathrm{K}$ & $\mathrm{Ca}$ & $\mathrm{Ba}$ & $\mathrm{Pb}$ & $\overline{Z n}$ & $\mathrm{Ni}$ & $\mathrm{Na}$ & $\mathrm{Mn}$ & $\mathrm{Mg}$ & $\mathrm{Cr}$ & $\mathrm{Cd}$ \\
\hline $\mathrm{Fe}$ & 1 & $0.262^{*}$ & 0.144 & 0.010 & 0.190 & 0.094 & 0.244 & 0.042 & 0.004 & 0.183 & 0.053 & 0.026 & 0.130 \\
\hline $\mathrm{Cu}$ & & 1 & $0.453 *$ & 0.064 & 0.114 & $0.480^{*}$ & $0.937 *$ & $0.485 *$ & 0.036 & 0.179 & 0.152 & $0.424 *$ & $0.649 *$ \\
\hline $\mathrm{K}$ & & & 1 & 0.127 & 0.078 & 0.242 & $0.462 *$ & $0.341 *$ & 0.118 & 0.133 & 0.070 & $0.274 *$ & $0.380 *$ \\
\hline $\mathrm{Ca}$ & & & & 1 & 0.089 & 0.013 & 0.041 & 0.026 & $0.920 *$ & $0.874 *$ & 0.027 & 0.073 & 0.089 \\
\hline $\mathrm{Ba}$ & & & & & 1 & 0.049 & 0.043 & 0.071 & 0.082 & 0.006 & 0.021 & 0.045 & 0.012 \\
\hline $\mathrm{Pb}$ & & & & & & 1 & $0.475^{*}$ & $0.356 *$ & 0.083 & 0.015 & 0.016 & $0.511 *$ & $0.793 *$ \\
\hline $\mathrm{Zn}$ & & & & & & & 1 & $0.333 *$ & 0.071 & 0.038 & 0.178 & $0.363 *$ & 0.658 * \\
\hline $\mathrm{Ni}$ & & & & & & & & 1 & 0.044 & 0.000 & 0.027 & $0.758 *$ & $0.527 *$ \\
\hline $\mathrm{Na}$ & & & & & & & & & 1 & $0.745^{*}$ & 0.020 & 0.064 & 0.016 \\
\hline Mn & & & & & & & & & & 1 & 0.014 & 0.390 & 0.124 \\
\hline $\mathrm{Mg}$ & & & & & & & & & & & 1 & 0.011 & 0.023 \\
\hline $\mathrm{Cr}$ & & & & & & & & & & & & 1 & $0.722 *$ \\
\hline $\mathrm{Cd}$ & & & & & & & & & & & & & 1 \\
\hline
\end{tabular}

* means significant correlation, $P<0.05$. 
Table 2. Inhibition of cell proliferation by heavy metals

\begin{tabular}{lccc}
\hline \hline & Control & $100 \mathrm{mg} / l$ & $10 \mathrm{mg} / l$ \\
\hline $\mathrm{Fe}$ & $1.811 \pm 0.350$ & $0.875 \pm 0.360^{*}$ & $1.850 \pm 0.421$ \\
$\mathrm{Cu}$ & $0.436 \pm 0.060$ & $0.124 \pm 0.035^{*}$ & $0.460 \pm 0.030$ \\
$\mathrm{Ca}$ & $0.319 \pm 0.051$ & $0.068 \pm 0.023^{*}$ & $0.357 \pm 0.041$ \\
$\mathrm{Zn}$ & $0.675 \pm 0.056$ & $0.088 \pm 0.031^{*}$ & $0.719 \pm 0.060$ \\
$\mathrm{Ni}$ & $0.668 \pm 0.094$ & $0.233 \pm 0.036^{*}$ & $0.574 \pm 0.068$ \\
$\mathrm{Mn}$ & $0.684 \pm 0.068$ & $0.423 \pm 0.054^{*}$ & $0.725 \pm 0.084$ \\
$\mathrm{Mg}$ & $0.936 \pm 0.200$ & $0.230 \pm 0.120^{*}$ & $1.126 \pm 0.217$ \\
$\mathrm{Cr}$ & $0.439 \pm 0.036$ & $0.120 \pm 0.017^{*}$ & $0.367 \pm 0.042$ \\
$\mathrm{Cd}$ & $1.204 \pm 0.062$ & $0.161 \pm 0.069^{*}$ & $0.265 \pm 0.102^{*}$ \\
\hline
\end{tabular}

${ }^{*}$ means significant difference, $P<0.05$ (Absorbance)

cell proliferation. HepG2 cell was exposed to $10 \mathrm{mg} / \mathrm{l}$ or $100 \mathrm{mg} / \mathrm{l}$ of iron, copper, calcium, zinc, nickel, manganese, magnesium, chromium and cadmium for 24 hours and the effect on the cell proliferation was observed. The cell proliferation of most of the heavy metal-treated groups was strongly inhibited at $100 \mathrm{mg} / \mathrm{l}$ of the heavy metal concentration (Table 2). The cell proliferation in all the heavy metaltreated groups was not inhibited at $10 \mathrm{mg} / \mathrm{l}$ of the heavy metal concentration, except the cadmium-treated group which showed a strong cell proliferation inhibition. This showed that cadmium has the potential to cause higher cell toxicity than other heavy metals, though a small amount of it exists in the subway stations.

\section{DISCUSSION}

According to the results of this study, the concentrations of iron and copper were relatively high in the subway station platforms. This is presumably the result of the defect generation by the friction between the rail and the trains and the friction between the copper lines for power transmission and the trains. When compared with the results from other countries, it was similar that the iron concentration was the highest, but the manganese and chromium concentrations were lower in this study. The causes for such differences may be the difference in the wheel and rail brake block materials, traffic density and passenger activity. One report mentioned that the particulate matter exposure of the subway passengers is higher than that of the taxi drivers (Pfeiffer et al., 1996). Chillrud (2004) analyzed the causes of heavy metal exposure by the students for 24 hours and reported that the exposure through the subway is the most in the exposure to heavy metals.

The results of our study showed strong correlations between a few major heavy metals in the subway station atmospheric particulate matter. The highest correlation among the major heavy metals was found between zinc and copper, which is presumably due to the use of copper-zinc alloy for electric devices (Shin et al., 2005). It can be expected that exposure to heavy metals in subway stations is usually simultaneous with exposure to various types of heavy metals rather than exposure to a single kind of heavy metal. Since the major heavy metals had high correlations between their concentrations, it is probable that at least some heavy metals may be from the same pollution sources such as subway materials, subway passengers, and floor. Further studies need to be continued regarding the sources of the atmospheric heavy metal particulate matter. In the future, the cell toxicity of simultaneous exposure to the heavy metals with high correlations should be investigated for the risk assessment of subway atmospheric particulate matter heavy metals.

At present, the risk assessment of subway-oriented heavy metal particulate matter to the living body is conducted mainly by in vitro human cell experiments. It has been reported that heavy metal particulate matter cause oxidative stress, DNA damage and inflammatory reaction (Karlsson et al., 2005, 2006; Seaton et al., 2005). The genotoxicity of the subway particles was comparable to that of welding fume particles to alveoloar epithelium cell (Seaton et al., 2005). Karlsson et al. (2005) report showed that the subway particles were more genotoxic to cultured human lung cell than urban street particles. In the results of our study, cadmium showed the highest cell proliferation inhibition. This showed that cadmium has the potential to cause higher cell toxicity than other heavy metals, though relatively small amount of it exists in the subway stations. Particular attention should be paid to cadmium concentration in the control of the subway atmospheric heavy metals in the future.

Since the exposure in subway stations is usually longterm low-concentration exposure, measures should be taken to minimize the risk of the low-concentration exposure by long-term passengers. While the air pollution in underground space is actively studied in foreign countries, relatively small numbers of researchers in Korea carry out the study on the heavy metals in relation to the indoor air pollution. The investigation of indoor pollutant concentration in subway stations is especially limited. As the number of subway passengers has increased recently, it is expected that the chronic exposure to the polluted indoor air in subway stations might cause a biohazard. Therefore, the research regarding indoor air pollution should be carried out continuously. At present, the risk of subway particulate matter to the living body has not been sufficiently studied. This study provides the fundamental data for the understanding of simultaneous heavy metal exposure tendency during the time of particulate matter exposure in subway stations and the identification of heavy metal sources. Moreover, this study can be used as the fundamental data for the cell toxicity study of heavy metal-containing particulate matter inside subway stations.

\section{ACKNOWLEDGEMENT}

This study was supported by Korea Research Foundation 
Grant funded by the Korean Government (KRF-2006-D00594).

\section{REFERENCES}

Aarnio, P., Yli-Tuomi, T., Kousa, A., Makela, T., Hirsikko, A., Hameri, K., Raisanen, M., Hillamo, R., Koskentalo, T. and Jantunen, M. (2005). The concentrations and composition of and exposure to fine particles (PM2.5) in the Helsinki subway system. Atmosph. Environ., 39, 5059-5066.

Adams, H.S. (2001). Exrosure assessment of urban transfort users to particulate air pollution. Ph.D., Imperial college London, Department of Environmental Science and Technology, University of London.

Boudia, N., Halley, R., Kennedy, G., Lambert, J., Gareau, L. and Zayed, J. (2006). Manganese concentrations in the air of the Montreal (Canada) subway in relation to surface automobile traffic density. Science Total Environ., 366, 143-147.

Chillrud, S.N., Epstein, D., Ross, J.M., Sax, S.N., Pederson, D., Spengler, J.D. and Kinney, P.L. (2004). Elevated airborne exposures of teenagers to manganese, chromium, and iron from steel dust and New York City's subway system. Environ. Science Technol., 38, 732-737.

Furuya, K., Kudo, Y., Okinagua, K., Yamuki, M., Takahashi, K., Araki, Y. and Hisamatsu, Y. (2001). Seasonal variation and their characterization of suspended particulate matter in the air of subway stations. J. Trace Micro. Tech., 19, 469-485.

Gomez-Perales, J.E. (2005). Commuter's exposure to air pollution in Mexico City. Ph.D., Imperial College London, Department of Environmental Science and Technology, University of London.

Hansen, M.B., Nielsen, S.E. and Berg, K. (1989). Re-examination and further development of a precise and rapid dye method for measuring cell growth/cell kill. J. Immunol. Methods, 119, 203210.

Harrison, R.M., Laxen, D.P.H. and Wilson, S.J. (1983). Chemical association of lead cadmium, copper, and zinc in street dusts and roadside soil. Environ. Sci. Technol., 15, 1378-1383.

Hopke, P.K., Lamb, R.E. and Natusch, D.F.S. (1980). Multi-elemental characterezation of urban roadway Dust. Envion. Sci. Technol., 14, 164-172.

Jeon, J.M., Kim, Y.S., Shin, H.S. and Chang, N.I. (1996). A Literature review on indoor air quality investigated in Seoul underground environments. J. K. Soc. Environ. Admin., 3, 24-34.

Jeong, Y., Jang, J.Y. and Joo, E.J. (1987). Mercury concentration in urban ambient air-based on the data aquired from Shinchon and Seoul. K. Soc. Atmos. Environ., 25, 18-26.

Johansson, C. and Johansson, P.A. (2003). Particulate matter in the underground of Stockholm. Atmospheric Environment, 37, 3-9.

Kang, S., Hwang, H., Park, Y., Kim, H. and Ro, C.U. (2008). Chemical compositions of subway particles in Seoul, Korea determined by a quantitative single particle analysis. Environ. Sci. Technol., 42, 9051-9057.
Karlsson, H.L., Ljungman, A.G., Lindbom, J. and Moller, L. (2006). Comparison of genotoxic and inflammatory effects of particles generated by wood combustion, a road simulator and collected from street and subway. Toxicol. Lett., 165, 203-211.

Karlsson, H.L., Nilsson, L. and Moller, L. (2005). Subway particles are more genotoxic than street particles and induce oxidative stress in cultured human lung cells. Chem. Res. Toxicol., 18, 19-23.

Kim, M.Y., Ra, S.H., Shin, D.C., Han, K.M., Choi, K.S. and Jeong, I.H. (1998). Distribution characteristics between line and line for indoor air pollutant factors at subway stations in Seoul area. K. J Environ. Health, 24, 134-144.

Kweon, S.H. and Son, D.H. (1985). Studies on the content of the heavy metals of total suspended particles in air. Chung-Ang J. Pharmacal Sci., 1, 15-29.

Lebowitz, M.D. (1996). Epidemiological studies of the respiratory effects of air pollution. Eur. Respir. J., 9, 1029-1054.

Nero, A.V. (1988). Controlling indoor air pollution. Sci. Am., 285, 42-48.

Park, H.K. (2004). A study of PM-10 and heavy metal characteristics in the air at the each site of a subway station. Kumoh National Institute of Technology, Gumi.

Pfeifer, G.D., Harrisonb, R.M. and Lynama, D.R. (1999). Personal exposures to airborne metals in London taxi drivers and office workers in 1995 and 1996. Science Total Environ., 235, 253260.

Pope, C.A. III, Deckery, D.W., Spengler, J.D. and Raizenne, M.E. (1991). Respiratory health PM 10 pollution. A daily time series analysis. Am. Rev. Resp. Dis., 144, 668-674.

Salma, I., Weidinger, T. and Maenhaut, W. (2007). Time-resolved mass concentration, composition and sources of aerosol particles in a metropolitan underground railway station. Atmosph. Environ., 41, 8391-8405.

Seaton, A., Cherrie, J., Dennekamp, M., Donaldson, K., Hurley, J.F. and Tran, C.L. (2005). The London underground: dust and hazards to health. Occup. Environ. Med., 62, 355-362.

Shin, J.H., Lee, J.B. and Shin, S.H. (2005). Evaluation of the resistance to corrosion of plated $\mathrm{Ni}-\mathrm{Cr}$ and bright $\mathrm{Ni}$-microporous $\mathrm{Cr}$ layers on Fe substrate by CASS and EC tests. J. K. Inst. Metals Materials, 43, 54-61.

Sitzmann, B., Kendal, M. and Williams, I. (1999). Characterisation of airborne particles in London by computer-controlled scanning electron microscopy. Sci. Total Environ., 241, 63-73.

Sysalovaa, J. and Szakovab, J. (2006). Mobility assessment and validation of toxic elements in tunnel dust samples; Subway and road using sequential chemical extraction and ICP-OES/ GFAAS measurements. Environ. Res., 101, 287-293.

Tichenor, B.A., Sparks, L.A., White, J.B. and Jackson, M.D. (1990). Evaluating sources of indoor air pollution. J. Air Waste Manage Assoc., 40, 487-492. 